\title{
抽出残渣分析技術および耐軟化特性に優れた $\mathrm{Cu}-\mathrm{Fe}-\mathrm{P}$ 系合金の開発
}

\section{1. はじめに}

$\mathrm{Cu}-\mathrm{Fe}-\mathrm{P}$ 系合金は析出硬化型合金で, IC リードフレーム などの高強度電子部品として広く使用されている. 近年，リ ードフレームの小型化, 薄型化, 多ピン化に伴い, 銅合金が 有する良好な電気伝導性と機械的特性, 特に強度や耐軟化特 性を更に向上させることが要求されている.

本合金の軟化挙動に及ぼす分散粒子の影響については, 従 来から多くの研究が行われている(1)-(5). 直径約 $1 \mu \mathrm{m}$ 以上 の粗大粒子は再結晶の主要な核形成サイトとなり, 粒子のサ イズが大きいほど再結晶核は形成しやすい(4). 一方で数 10 $\mathrm{nm}$ 以下の微細な粒子が密に分散するほど, ピン止め力によ る粒界移動の拘束力が大きくなり，再結晶を抑制する.した がって, 数 nm レベルから数 $\mu \mathrm{m}$ レベルまで分布する分散粒 子のサイズと量を定量的に評価し, 分散状態が及ぼす影響に ついて調査を行うことが重要である.

しかしながら，固溶量や分散粒子量を直接的に評価する手 法がなかったため, 従来の研究では, 粒子サイズや体積率の 測定が，SEM や TEM を用いた微小領域での評価手法に依 存し, 観察視野が限定されるために統計信頼性がなく, 定量 的議論ができていなかった.

そこで著者らは，まず溶液中で銅マトリックスおよび固溶 元素のアンミン錯体を形成させることに着目し，分散粒子形 態のみを抽出して定量分析を行う抽出残椬分析法を新しく開 発した. 今回，この分析方法を用いて， $\mathrm{Cu}-\mathrm{Fe}-\mathrm{P}$ 系合金中 の粗大粒子および微細粒子の量の割合を定量的に評価し，そ

* 株式会社神戸製鋼所

材料研究所 : 1) 研究員 2)主任研究員 長府製造所 : 3 )主任部員

** 株式会社コベルコ科研環境化学事業部主幹

Development of Extracted Residue Analysis Method and $\mathrm{Cu}^{-}$ Fe-P Alloy with Excellent Softening Resistance; Yasuhiro Aruga*, Katsura Kajihara*, Naohiro Hara**, Yosuke Miwa* (*Kobe Steel Ltd. ${ }^{* *}$ Kobelco Research Institute, Inc.) 2005 年 10 月 24 日受理

\section{有 賀 康 博当) 梶 原桂炎 \\ 原 \\ 直 広** 三 輪 洋 介光}

れぞれの量が軟化特性に及ぼす影響を調査した。そして，特 に微細粒子量増加によって耐軟化特性が著しく向上する知見 を当社製品に適用し，耐軟化特性に優れた KLF194 を開発 した.

\section{2. 抽出残椬分析法の開発}

従来から，金属材料の諸特性に大きな影響を及ぼす析出物 の量や形態を調べるために, 化学的手法による分離定量方法 が種々検討されてきた．その結果，鉄鋼材料では非水系溶媒 を用いた電解抽出法, アルミニウムでは熱フェノール抽出法 などが開発され，材料開発に大きく寄与しているが，銅合金 については析出物の分離分析に関する研究はほとんど行われ ていない。

そこで我々は，溶液中で銅マトリックスおよび固溶元素の アンミン錯体を形成させることに着目し，アミノ基 $\left(\mathrm{NH}_{2}\right.$ 基)を含む化合物またはアンモニウム塩を非水系溶媒に溶解 し，これを電解液とした電解抽出法を用いれば，銅マトリッ クスおよび固溶元素のみ溶解し，合金中の分散粒子を溶失せ ずに抽出できることを見出した．これより，分散粒子量の測 定は，酢酸アンモニウムーメタノール溶液を用いて銅マトリ ックス抢よび固溶元素を溶解させた後, メンブランフィルタ 一(ポアサイズ $1 \mu \mathrm{m}, 0.1 \mu \mathrm{m}$ ) を用いて反応液を吸引ろ過 し, 残渣を抽出してから ICP 発光分光分析法にて定量分析 を行った。

\section{3. サイズごとの分散粒子量および固溶量の評価}

表 1 に示す化学成分の C194 合金を, 1273 K, 1 h の溶体

表 1 C194試料の化学成分 (mass\%).

\begin{tabular}{cccc}
\hline \hline $\mathrm{Fe}$ & $\mathrm{P}$ & $\mathrm{Zn}$ & $\mathrm{Cu}$ \\
\hline 2.22 & 0.033 & 0.14 & Rem. \\
\hline
\end{tabular}


化処理後, 表 2 に示す 3 通りの時効処理を行い, $0.20 \mathrm{mmt}$ まで冷延を行った。本試料を用いて, 開発した抽出残椬分析 法による分析を行った. ポアサイズ $0.1 \mu \mathrm{m}$ のフィルターに よって抽出した残渣のSEM 像を図 1 に示す。残椬として得 られた粒子は， Fe，または Fe と P の化合物であり, 冷延板 に存在している分散粒子を溶失させることなく抽出している.

各試料の抽出残椬に含まれる $\mathrm{Fe}$ と $\mathrm{P}$ 量の分析結果を表 3 に示す． Fe 量はいずれの試料も約 1.5 mass\%であり, 総 添加量の約 $70 \%$ をめている。一力で P 量は, 試料 1 と 2 が総添加量と同值の 0.033 mass \%であるのに対し，試料 3 は 0.026 mass\%である。したがって，試料 1,2 に含まれる $\mathrm{P}$ は全て Fe と $\mathrm{P}$ の化合物として存在し, 試料 3 では 0.007 $\operatorname{mass} \%$ P が固溶している.

次に，各試料における粒子サイズごとの $\mathrm{Fe}$ 量の割合を図 2 に示す. 各試料ともに $0.1 \mu \mathrm{m}$ 末満の微細粒子量( 以降 $\mathrm{Fe}_{\mathrm{f}}$ と呼ぶ), 固溶量 (以降 $\mathrm{Fe}_{\mathrm{s}}$ と呼ぶ)の和が約 0.7 mass \% で, 総添加量の約 $30 \%$ である. 本分析法では $\mathrm{Fe}_{\mathrm{f}}$ と $\mathrm{Fe}_{\mathrm{s}}$ を分離す ることはできないが，各試料の導電率の違いは固溶量の違い によるものと仮定し，各元素の電気抵抗に及ぼす寄与度 ${ }^{(6)}$ 加 ら換算して，各試料に抢ける粒子サイズごとの Fe 量の割合 を評価した (7). $1 \mu \mathrm{m}$ 以上の粗大粒子量( 以降 $\mathrm{Fe}_{\mathrm{c}}$ と呼ぶ) は, 試料 1 よりも試料 2 が 0.22 mass\%多いが, $\mathrm{Fe}_{\mathrm{f}}$ と $\mathrm{Fe}_{\mathrm{s}}$ は同等である。また, 試料 2 の $\mathrm{Fe}_{\mathrm{f}}$ は試料 3 よりも 0.38

表 2 各試料の時効処理条件.

\begin{tabular}{cc}
\hline \hline 試料 1 & $773 \mathrm{~K}, 4 \mathrm{~h}$ \\
\hline 試料 2 & $1073 \mathrm{~K}, 2 \mathrm{~h}+773 \mathrm{~K}, 4 \mathrm{~h}$ \\
\hline 試料 3 & $1073 \mathrm{~K}, 2 \mathrm{~h}$ \\
\hline
\end{tabular}

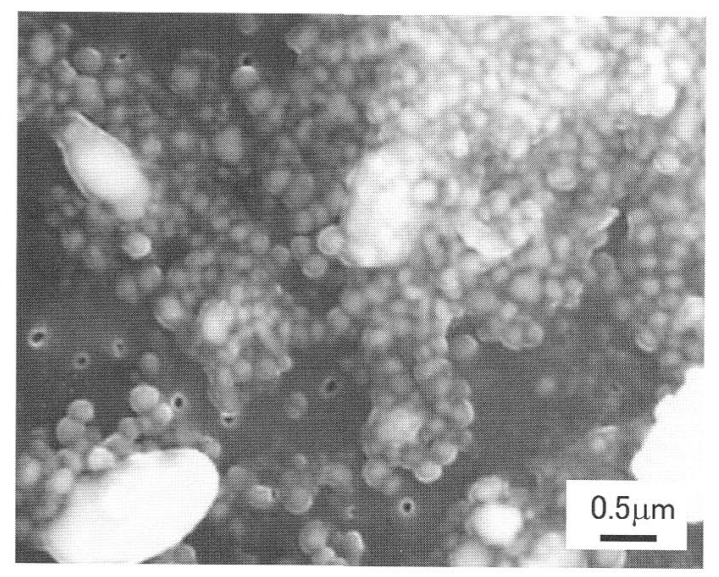

図 1 開発分析法にて抽出した粒子の SEM 像.

表 3 抽出残椬に含まれる $\mathrm{Fe}$ および $\mathrm{P}$ 量.

\begin{tabular}{ccc}
\hline & $\mathrm{Fe}$ & $\mathrm{P}$ \\
\hline 試料 1 & 1.54 & 0.033 \\
\hline 試料 2 & 1.51 & 0.033 \\
\hline 試料 3 & 1.48 & 0.026 \\
\hline
\end{tabular}

$\operatorname{mass} \%$ 多い.

\section{4. 軟化特性に及ぼす粗大および微細粒子量の影響}

各試料の軟化特性を図 3 に示す. 他試料よりも粗大粒子量 が少なく，微細粒子量が多い試料 1 が最も軟化しにくい。 微細粒子量が少ない試料 3 が最も低温で軟化している.

前記のように, 試料 3 は他試料よりも固溶 $\mathrm{Fe}$ 量が 0.38 mass\%多く, P が 0.007 mass\%固溶している.つまり,こ れら固溶量の増加分による軟化の抑制効果が試料 3 のみに 作用している。鈴木ら ${ }^{(8)}$ によれば，P が 0.007 mass \% 固溶 することで, 純銅の半㳄化温度 $\left(\mathrm{T}_{\mathrm{H}}\right.$ : 冷間师工による硬化量 が $1 / 2$ に減少する焼鈍温度) が $90 \mathrm{~K}$ 上昇する。これに從え ば，固溶 P 量の影響を除いた場合の軟化曲線は, 図 3 中の 試料 3 \# と予測される。 つ李り, 試料 3 は固溶 $\mathrm{P}$ による軟化 の抑制を除くと， $700 \mathrm{~K}$ 以下で大きく軟化すると考えりれる.

試料 1 と 2 の差異は, 試料 2 の粗大粒子量 $\mathrm{Fe}_{\mathrm{c}}$ が試料 1 に比べて 0.22 mass\%多いことである. 雨試料における粗大 粒子の平均サイズは同等であり, 粗大粒子量の増加はほぼ数 密度の増加とみなすことができる。これら粗大粒子は, 再結 晶の核生成サイトになって軟化を促進することが知られてい る(4). したがって, 両試料の粗大粒子量の差から, 試料 2 は試料 1 よりも再結晶核の形成頻度が約 1.25 倍高いと推定

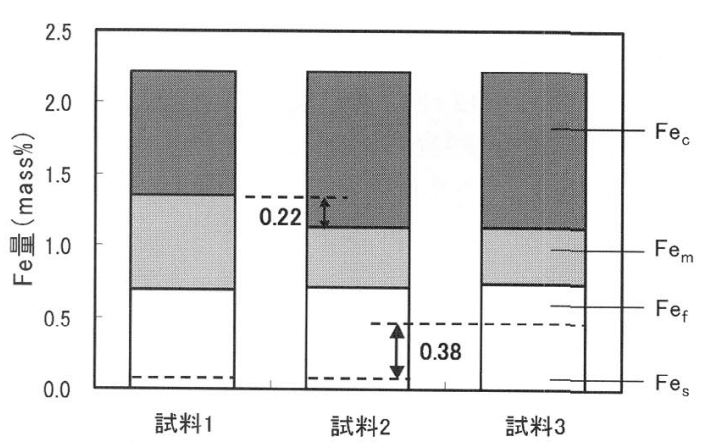

図 2 各試料に抢ける粒子サイズごとの $\mathrm{Fe}$ 量の割合 $\left(\mathrm{Fe}_{\mathrm{c}}\right.$ : $1 \mu \mathrm{m}$ 以上の粒子, $\mathrm{Fe}_{\mathrm{m}}: 0.1 \mu \mathrm{m}$ 以上 1 $\mu \mathrm{m}$ 未満の粒子, $\mathrm{Fe}_{\mathrm{f}}: 0.1 \mu \mathrm{m}$ 未満の粒子, $\mathrm{Fe}_{\mathrm{s}}$ ： 固溶体)。

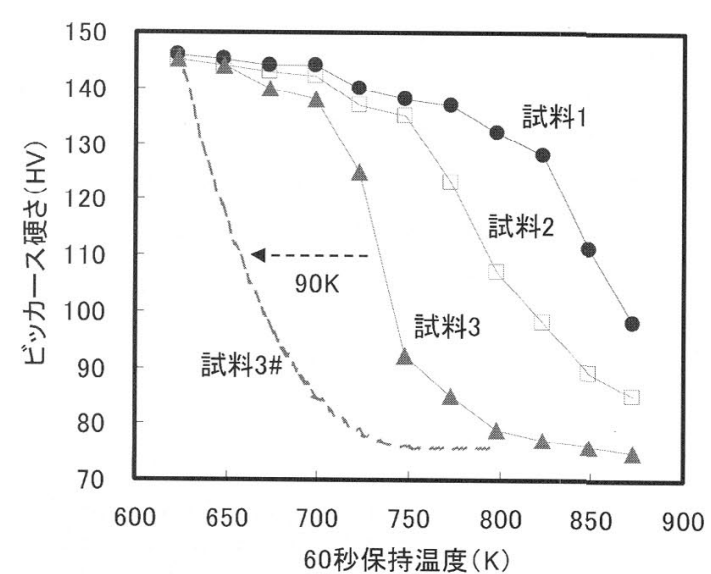

図 3 各試料の軟化特性. 
され，その影響で $\mathrm{T}_{\mathrm{H}}$ が約 $50 \mathrm{~K}$ 低下していると解釈される.

一方で, 試料 2 と 3 では, 試料 2 の方が微細粒子量 $\mathrm{Fe}_{\mathrm{f}}$ が 0.38 mass\%多い, 微細粒子量の少ない試料 3 は, 固溶量 の影響を除くと, 試料 2 よりも $\mathrm{T}_{\mathrm{H}}$ が約 $150 \mathrm{~K}$ 低い. 両試料 における微細粒子の平均サイズは同等である.すなわち, わ ずかな微細粒子量の増加が，転位や粒界移動の拘束力を著し く増加させ，回復・再結晶を抑制していると考えられる。

析出物による転位および粒界移動の拘束力 $F$ は, 次式に 示すZ Zener drag の式で記述されている(9).

$$
F=\frac{3 f \gamma}{2 r}
$$

$r$ と $f$ それぞれ粒子の平均半径と体積率, $\gamma$ は粒界エネル ギーである. 試料 2 と 3 の $r$ は同等で, $\gamma$ も等しいとみなせ る. したがって, 試料 2 における拘束力と, 試料 3 の拘束 力の差は, 両試料の微細粒子の体積率の差で決まる.

ここで, 各試料における微細粒子の体積率を定量化するた め, 市販の $\mathrm{Cu}$ 基合金の熱力学データベースを用いて, CALPHAD 法による状態図計算を行った ${ }^{(10)}$. それによれ ば，本試料の組成では， $773 \mathrm{~K}$ の平衡状態で 0.06 mass\%の $\mathrm{Fe}$ が固溶する. 試料 2 で行った $773 \mathrm{~K}$ で 4 時間の時効によ って平衡状態に達していると仮定すれば, 試料 2 の固溶量 $\mathrm{Fe}_{\mathrm{s}}$ が 0.06 mass \%, 微細粒子量 $\mathrm{Fe}_{\mathrm{f}}$ が 0.65 mass\%となる. 試料 3 の $\mathrm{Fe}_{\mathrm{f}}$ は試料 2 よりも 0.38 mass\%少ないため, 0.27 mass\%となる. したがって, 試料 2 における拘束力は, 試 料 3 に打ける拘束力よりも約 2.4 倍大きく, 転位や粒界の移 動を抑制して， $\mathrm{T}_{\mathrm{H}}$ を約 $150 \mathrm{~K}$ 上昇させていると推察される.

\section{5. 耐軟化特性に優れた KLF194の開発}

以上より, 微細粒子量増加によって耐軟化特性が著しく向 上することを見出し，この材料設計指針を当社リードフレー 厶用銅合金 KLF194 に適用した。開発材の機械的性質およ び導電率を表 4 に，軟化特性を図 4 に示す。開発材は, 773 $\mathrm{K}$ で加熱しても 150 以上の HV 值を維持しており, 従来材 に比べて軟化温度が約 $50 \mathrm{~K}$ 高い. 分散粒子の精密な制御に よって，耐軟化特性に優れた KLF194を開発した。
表 4 KLF194開発材の機械的特性と導電率.

\begin{tabular}{ccccc}
\hline \hline $\begin{array}{c}\text { 引張強さ } \\
(\mathrm{MPa})\end{array}$ & $\begin{array}{c}\text { 耐力 } \\
(\mathrm{MPa})\end{array}$ & $\begin{array}{c}\text { 伸び } \\
(\%)\end{array}$ & $\begin{array}{c}\text { ビッカース } \\
\text { 硬さ }(\mathrm{HV})\end{array}$ & $\begin{array}{c}\text { 導電率 } \\
\text { \% }\end{array}$ \\
\hline 573 & 549 & 5 & 169 & 70 \\
\hline
\end{tabular}

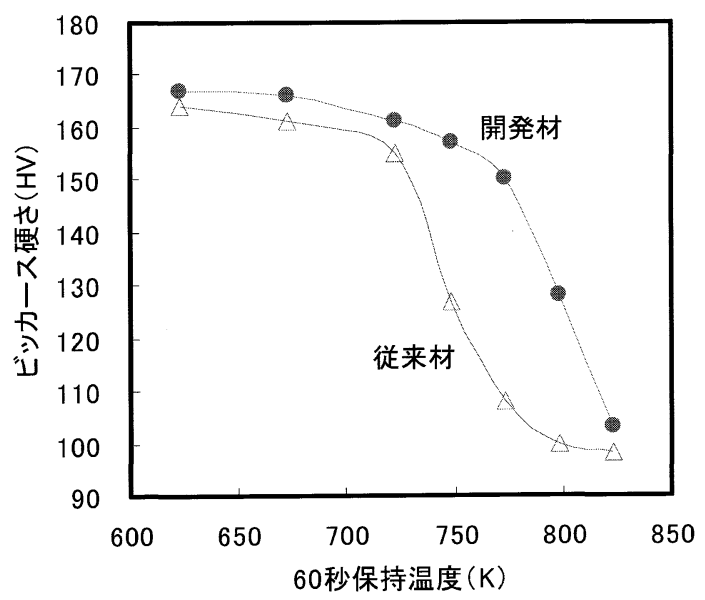

図 4 KLF194 開発材の軟化特性.

\section{6. 特 許}

抽出残渣分析法および材料特許を出願しており，特開 2004-4009など 6 件が公開，うち 1 件が登録となっている.

\section{文献}

（1）美馬源次郎，堀 茂徳，佐治重興，富永幸克：日本金属学会 誌, 33(1969), 521.

（2）堀 茂徳, 佐治重興: 伸銅技術研究会誌, 11(1972), 166 .

(3) 高橋恒夫, 神尾彰彦, 村上 雄, 手塚裕康, 永田信 : 伸銅 技術研究会誌, 17(1978), 82 .

（4）大迫敏行，横沢公一，風間敬三，鈴木 寿：伸銅技術研究会 誌, 28(1989), 133.

(5) 北 和久, 小林一徳, 門前亮一: 材料, $49(2000), 482$.

(6) J. O. Linde: Ann. d. Phys., 15(1932), 219.

（7）有賀康博，梶原 桂，原 直広：銅と銅合金，43(2004), 74

（8）鈴木 寿，菅野幹宏，前田貴雄：日本金属学会誌， 47(1983), 794.

( 9 ) C. S. Smith: Trans. Metall. Soc. AIME, 175(1948), 15.

(10) 石田清仁 : 第43回銅および銅合金技術研究会講演大会講演概 要集, $(2003), 1$. 